\title{
Using Scrambled Pictures Media to Improve Students' Writing Skill in Narrative Text
}

\author{
Anfinda Mutiara Kasih \& Kurniawan Kurniawan \\ Universitas Lancang Kuning. Pekanbaru. Indonesia \\ anfinda.mk@gmail.com
}

ARTICLE HISTO
$\begin{array}{ll}\text { Received } & : 2019-07-26 \\ \text { Revised } & : 2019-08-02 \\ \text { Accepted } & : 2019-11-22\end{array}$

\section{KEYWORDS}

Writing Skill

Scrambled Picture Media

Classroom Action Research

Eighth Grade Students

\begin{abstract}
The present Classroom Action Research (CAR) initiated when the researcher found the students at the eighth-grade students of SMP Juara Pekanbaru had low writing skills. This problem could be identified from their base scores below the standard minimum score (GPA). It was 64,06. The purpose of this research was to try to develop the students' writing skill and to know the factors that influenced the changing of students' writing skill. This research was conducted from March up to May 2019 in two cycles consisted of ten meetings. The participants of this research were 27 students of the Andalusia class. In improving the students' writing skill, a narrative text was used as a learning media. The instruments used in this research were writing test, interview, field note and also observation list to help understand the phenomenon. This research showed that the students got the score 72,22 in cycle 1 dan 84,49 in cycle 2 , especially on organization with an increase of 4,47 . It could be seen that scrambled pictures media could improve the students' writing skill.
\end{abstract}

\section{Introduction}

The Indonesian government has established English as the number one foreign language, which constitutes one of the obligatory subjects taught in Junior High School based on curriculum 2013. Therefore, English was taught in SMP Juara Pekanbaru. However, based on the interview with the English teacher, the students have some problems in writing. First, they were difficult in getting the idea to write with. They did not know how to express what they had got in their mind. Second, they did not have enough vocabularies to express what they had thought because they only know some English words. Third, they did not comprehend the rules of English grammatically, so they made many errors in sentence structures in writing. The last, they sometimes forgot to write some parts of the story.

The researcher then highlighted these phenomena and started to initiate a writing skill as the topic of research that discussed how to raise students' understanding in generating ideas, how to organize ideas coherently, how to use discourse makers and rhetorical conventions to put them cohesively into a written text, how to revise text for clearer meaning, how to revise text for clearer meaning, how to edit text for appropriate grammar and how to produce a final product that includes content, organization, vocabulary use, grammatical use, and mechanical considerations such as spelling and punctuation.
In achieving these aims, the researcher believed scrambled pictures media in the narrative text as the media and material in teaching writing will overcome the situation. Furthermore, the researcher chosen scrambled pictures media in teaching writing narrative text because several researchers successfully applied scrambled pictures as a good medium to be used in teaching writing narrative text, and it can also help the students to write narrative text and explore the ideas about the narrative text. (Khasanah (2015). The scrambled picture is.

Echoing the ideas and discussion above, this study believed scrambled pictures as teaching media could help the students to improve the students' writing skill. And make them enjoy the teaching-learning process and, in the end, be able to comprehend writing narrative easily. This research also highlighted the media could be fill the gaps on the writing research by promoting an alternative and cheaper method to help to transfer the message and give power to the material presented so the material will be easy to understand and stay longer in the students' memory for Junior High School in Indonesian urban location context.

\section{Method}

The present research design would use Classroom Action Research (CAR) in improving the students' writing mastery of narrative text. CAR believed to be more suitable for the research since this study was 
related to the field case study. The research was conducted in SMP Juara Pekanbaru at the eighth-grade students in the second semester of the academic year 2018/2019. There were 2 classes of eighth-grade students at SMP Juara Pekanbaru; Cordova and Andalusia. The researcher took the Andalusia class as the subject of this research. The total number of students in the Andalusia class was 27. Andalusia class had been chosen because most of them have a problem in writing, especially in writing narrative text. This identified after the researcher interviewed the English teacher. He said in the interview (see appendix 5) that most of the students in Andalusia class were confused when the teacher asked them to write. The students encountered problems in writing narrative text.

There were two types of instruments used in this research: quantitative instruments and qualitative instruments.

\subsection{Instruments}

\section{a) Test}

The test was used to measure the students' writing narrative text after using the scrambled picture method. The test materials would be based on the curriculum and syllabus. The themes used in the test obtained from the most popular narrative stories that the students have known. To expand the discussion, the researcher gave 20 titles to the students, and the students choose 10 . After determining the titles, the students gave the paper to the researcher to see the familiarity (see appendix 3). The test gave at the end of each cycle. According to Oshima and Hogue (2007), to give a score of students writing paragraph used the rubric that will be scored in term of punctuation and mechanic, content, organization and grammar. It can be shown descriptively with the following table:

Table 1. The Rubric Scoring for Narrative Text Writing Assessment

\begin{tabular}{lcc}
\hline & Max & Actual \\
Pcore & Score \\
\hline PUNCTUATION AND MECHANICS - 5 POINTS & $\mathbf{1}$ \\
\hline There is a period after every sentence. & $\mathbf{1}$ \\
\hline Capital letters are used correctly. & $\mathbf{2}$ \\
\hline The spellings are correct. & $\mathbf{1}$ \\
\hline Capitalization \& other punctuations are used correctly. & $\mathbf{5}$
\end{tabular}

\begin{tabular}{|c|c|}
\hline CONTENT - 20 POINTS & \\
\hline The paragraph fits the assignment. & 4 \\
\hline The paragraph is unity. & 8 \\
\hline The paragraph is coherent. & 8 \\
\hline & Total 20 \\
\hline
\end{tabular}

The paragraph begins with a clear orientation about the 10 background of the story.

\begin{tabular}{|c|c|}
\hline $\begin{array}{l}\text { The paragraph contains complication in which the problem } \\
\text { arises, followed by other problem. }\end{array}$ & 25 \\
\hline The paragraph ends with an appropriate resolution. & 5 \\
\hline Total & 40 \\
\hline \multicolumn{2}{|l|}{ GRAMMAR \& SENTENCE STRUCTURE - 30 POINTS } \\
\hline Estimate a grammar and sentence structure score. & 30 \\
\hline Total & 30 \\
\hline GRAND TOTAL & 100 \\
\hline
\end{tabular}




\section{b) Observation Checklist}

The researcher used the observation checklist to find out the data about applying scrambled pictures in teaching writing narrative text.

\subsection{Procedure}

The design of classroom action research in the present study was a process that consisted of four steps: plan, action, observation and reflection by Kemmis and Mac Taggart (2007). The procedures of classroom action research in this research were as follows:

\subsubsection{Plan}

The researcher used scrambled pictures as media in teaching writing narrative text. In this step, the teacher plans everything to the action that would be implemented in the classroom.

\subsubsection{Action}

In this step, the researcher implemented the activities of teaching scrambled pictures in the teaching-learning process.

\subsubsection{Observation}

In this step, the researcher observed the activities that would be happening during the teaching and learning process. The researcher shared all of the results of the teaching-learning process with a rater.

\subsubsection{Reflection}

In the last, the researcher analyzed the result of the observation. The result of the reflection determined whether cycle 2 needed or not. The research stopped if the purpose of the research was achieved. However, if the research purpose was not achieved, the researcher would be continued to cycle 2 .

\subsection{The technique of Collecting Data}

In collecting the quantitative data, the researcher asked the students to write a famous fairy tale story structurally as a test. The test gave to the students at the end of each cycle. The test materials were based on the school's curriculum and syllabus. The purpose of the test was to know the students' writing mastery in writing narrative text. While, in collecting the qualitative data, the researcher interviewed each of the students, and then the researcher observed the students' responses. The interview gave to each of the students at the end of each cycle. The data used to find their opinions about the implementation of the method of the scrambled picture in mastering writing narrative text.

\subsection{Technique of Analyzing the Data}

\subsubsection{Analyzing Quantitative Data}

In analyzing the quantitative data, the researcher found the mean from all of the students' scores using the formula proposed by Sudijono (2009).

$$
\mathbf{M x}=\frac{\sum \mathbf{X}}{\mathbf{N}}
$$

$\mathrm{Mx}=$ Mean.

$\sum X \quad=$ Amount of the score.

$\mathrm{N}=$ Number of the participants.

Moreover, the researcher used an interval of the students passing score of Kriteria Ketuntsan Minimal $(K K M)$ from the school.

Table 2. The KKM Passing Score

\begin{tabular}{lll}
\hline No & Score Range & Category \\
\hline $\mathbf{1}$ & $75-100$ & Pass \\
\hline $\mathbf{2}$ & $0-74$ & Fail \\
\hline
\end{tabular}

\subsubsection{Analyzing Qualitative Data}

In analyzing the qualitative data, the researcher used 5 steps as Gay and Airasian (2000) formulated. Those 5 steps are:

a) Data managing: the data was collected from all the observation and interview field note from the responses of the students' interview.

b) Reading and memoing: after collecting the result of the observation, the researcher read the qualitative data. During reading the data, the researcher wrote some notes about the data, such as comments.

c) Describing: the researcher made a description from the memo that the researcher made at the "reading and memoing" step.

d) Classifying: after describing the qualitative data, the researcher classified the data based on the categories and specification.

e) Interpreting: in the last step, the researcher interpreted all the qualitative data into the conclusion that answer the research question about the implementation and students' perception toward applying the method of the scrambled picture in teaching writing narrative text.

\section{Findings and Discussion}

The researcher had found the research findings were increased during the teaching-learning process. The scrambled pictures media was applied in order to improve the students' writing skill. The research was conducted at the eighth-grade students of SMP Juara Pekanbaru from March until May 2019. The class that the researcher had taken was called Andalusia. Andalusia class consisted of 27 students.

The research was done in two cycles with consisted of five meetings every cycle. The duration of each meeting was $2 \times 40$ minutes. In the last meeting of each cycle, the researcher conducted a cycle test to improve the students' writing skill. 


\subsection{The Extent to which Scrambled Pictures Media could Improve Students' Writing Skill}

The research conducted classroom action research in two cycles. After the cycle was done, the researcher conducted a cycle test to know the improvement of the students' writing skill.

The purpose of this research was to help students in learning to write narrative text. The effort to improve the students' writing skill was proven by applying scrambled pictures media in the teaching-learning process. The description of the research implementation can be explained as follows:

\section{Cycle I}

a) Planning

Based on the interview with the English teacher, the researcher prepared the research. The researcher and the English teacher Mr. Mardiansyah, S.Pd. as the collaborator, designed three meetings for the teachinglearning process and a meeting for the cycle test. The researcher was hoped that the students' writing skill would be better after the researcher implemented the scrambled pictures media

Table 3. The Schedule for Cycle 1

\begin{tabular}{ccc}
\hline Meeting & Material & Date \\
\hline 1 & $\begin{array}{c}\text { Base score test, Implemented scrambled } \\
\text { pictures media: Cinderella }\end{array}$ & Tuesday, March 26 2019 \\
\hline 2 & $\begin{array}{c}\text { Implemented scrambled pictures media: } \\
\text { Cinderella }\end{array}$ & Monday, April 1 2019 \\
\hline 3 & Implemented scrambled pictures media: Little \\
match girl & Tuesday, April 2 2019 \\
\hline 4 & Implemented scrambled pictures media: & Pinocchio \\
\hline 5 & Test cycle 1 & Tuesday, April 16 2019 \\
\hline
\end{tabular}

\section{b) Action}

The researcher was taught the students by using the scrambled pictures media in the class. The teaching-learning process implemented three stages: pre activities, leading activities, and post activities as the researcher planned in the lesson plan.The preteaching activities include all done as opening the teaching-learning process, such as greeting and checking attendance. After that, the researcher told the students about a story than ask the students to guess what topic would be discussed. The main activities were the students' involvement in writing narrative text by applied the scrambled pictures media with their groups and individuals. After that they collected their texts to the researcher as the teacher. The post activities were reviewing the lesson and all done as closing.
Here, the description of the action that was the researcher implements as bellow:

\section{(i) Based Score}

For the first step before the researcher involved the students in the research, the researcher had to get the students' writing score by testing them to write a narrative text based on the researcher's topics. The test was based on the score of students writing skill before the researcher applied scrambled pictures media to identify the students' writing narrative text improvement. The average the students' base score was 65,60 . Based on the students' achievement, the students were not able to pass.

Table 4. Students' Writing Skill Base Score

\begin{tabular}{cccccc}
\hline $\begin{array}{c}\text { Name of } \\
\text { Score }\end{array}$ & P & C & O & G & Score \\
\hline Rater 1 Score & 4,30 & 15,04 & 27,22 & 15,93 & 62,48 \\
\hline Rater 2 Score & 6,33 & 14,04 & 23,52 & 15,81 & 59,70 \\
\hline Rater 3 Score & 4,37 & 16,93 & 27,78 & 20,93 & 70,00 \\
\hline
\end{tabular}




\begin{tabular}{llllll}
\hline $\begin{array}{l}\text { Based Score } \\
\text { (The mean) }\end{array}$ & 5 & 15,34 & 26,17 & 17,56 & 64,06 \\
\hline
\end{tabular}

$\begin{array}{lll}\text { Category } & \text { Fail }\end{array}$
F : Format
O : Organization
P: Punctuation and mechanics
G: Grammar and sentence structure

C: Content

Diagram 1: Students' Writing Skill Base Score

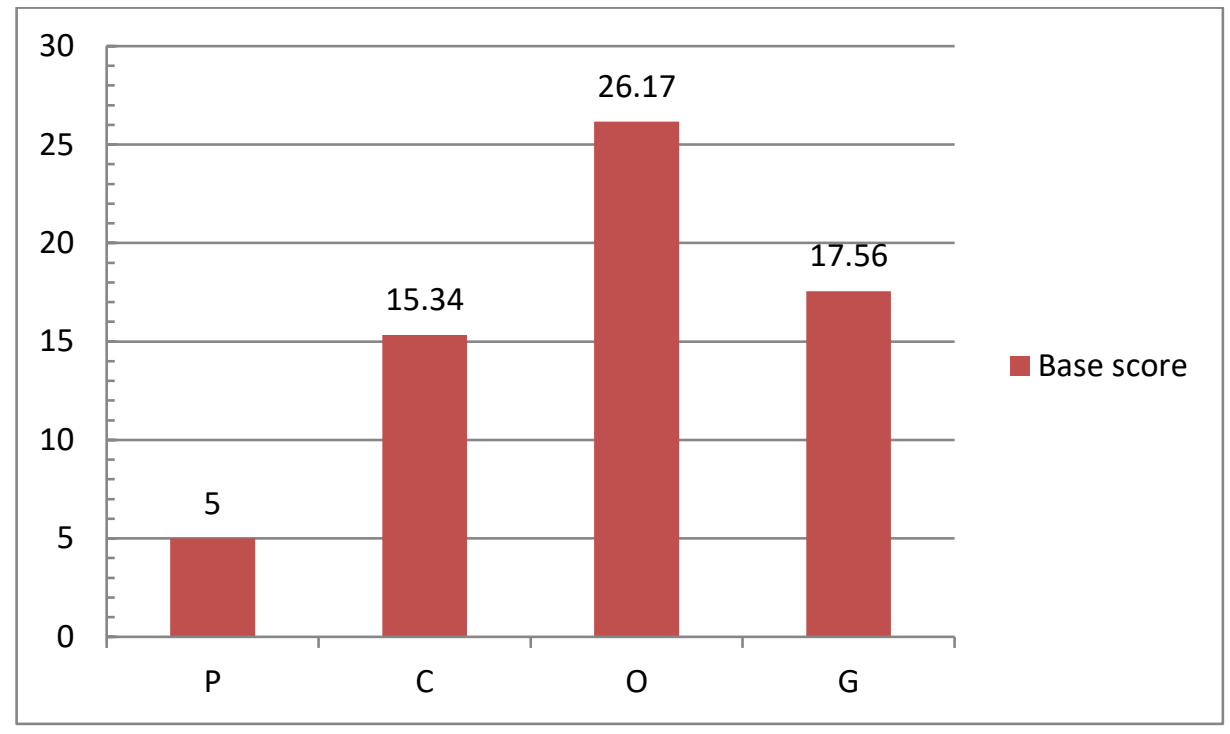

From the diagram above, it concluded that the students' writing score in the base score was failing, and the students' writing score was not able to pass.

\section{(ii) The Result of cycle 1}

By implemented scrambled picture media, the researcher got the result of the cycle 1 test score. The students' mean score in cycle 1 was 72,22 . According to the school's standard minimum, as explained in the previous chapter, the students were failed. It showed that the students failed by using scrambled picture media in the learning process. Comparing the base score to the cycle 1 score showed that there was some improvement between the base score and the cycle 1 score. To get the cycle 1 score, the researcher conducted cycle 1 with a systematic process as plan, action, observation and reflection.

After doing all those processes planned, the researcher gave the writing test to the students. The average score of cycle 1 was recapitulated as bellow:

Table 5 Table of Students' Writing Score In Cycle 1

\begin{tabular}{cccccc}
\hline $\begin{array}{c}\text { Name of } \\
\text { Score }\end{array}$ & P & C & O & G & Score \\
\hline Rater 1 Score & 4,56 & 17,52 & 30,56 & 23,52 & 76,15 \\
\hline Rater 2 Score & 6,70 & 15,11 & 24,48 & 18,96 & 65,26 \\
\hline $\begin{array}{c}\text { Rater 3 } \\
\text { Score }\end{array}$ & 4,48 & 18 & 29,44 & 23,89 & 75,81 \\
\hline $\begin{array}{c}\text { Cycle 1 Score } \\
\text { (The mean) }\end{array}$ & $\mathbf{5 , 2 5}$ & $\mathbf{1 6 , 8 8}$ & $\mathbf{2 8 , 1 6}$ & $\mathbf{2 2 , 1 2}$ & $\mathbf{7 2 . 2 2}$ \\
\hline Category & & & & & Fail \\
\hline
\end{tabular}


Diagram 2: The point of the students' writing aspects in cycle 1

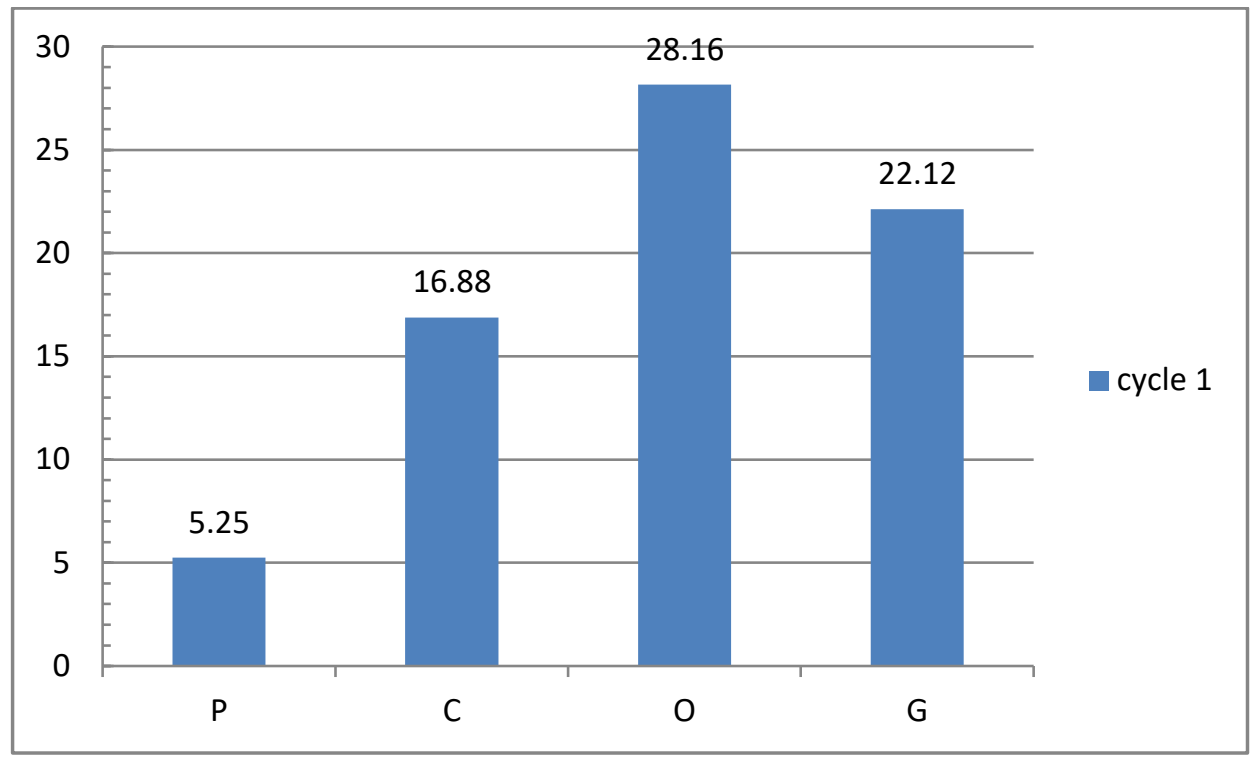

From the tables 4 and 5 and diagrams 1 and 2 it was identified that the students' writing score was improved. To support the statement above, the

researcher appended the score recapitulations. The improvement point of writing aspects showed as the table below:

Table 6 Improvement point of writing aspects in cycle 1

\begin{tabular}{ccccccc}
\hline $\begin{array}{c}\text { Name of } \\
\text { Score }\end{array}$ & $\mathbf{P}$ & $\mathbf{C}$ & $\mathbf{O}$ & $\mathbf{G}$ & Score & Category \\
\hline Base Score & 5 & 15,34 & 26,17 & 17,56 & 64,06 & Fail \\
\hline $\begin{array}{c}\text { Cycle 1 } \\
\text { Score }\end{array}$ & 5,25 & 16,88 & 28,16 & 22,12 & 72.22 & Fail \\
\hline $\begin{array}{c}\text { Improving } \\
\text { Impros }\end{array}$ & $\mathbf{1 , 5 4}$ & $\mathbf{1 , 9 9}$ & $\mathbf{4 , 5 6}$ & $\mathbf{8 , 1 6}$ & \\
\hline
\end{tabular}

Diagram 3: Improvement Point of Writing Aspects in Cycle 1

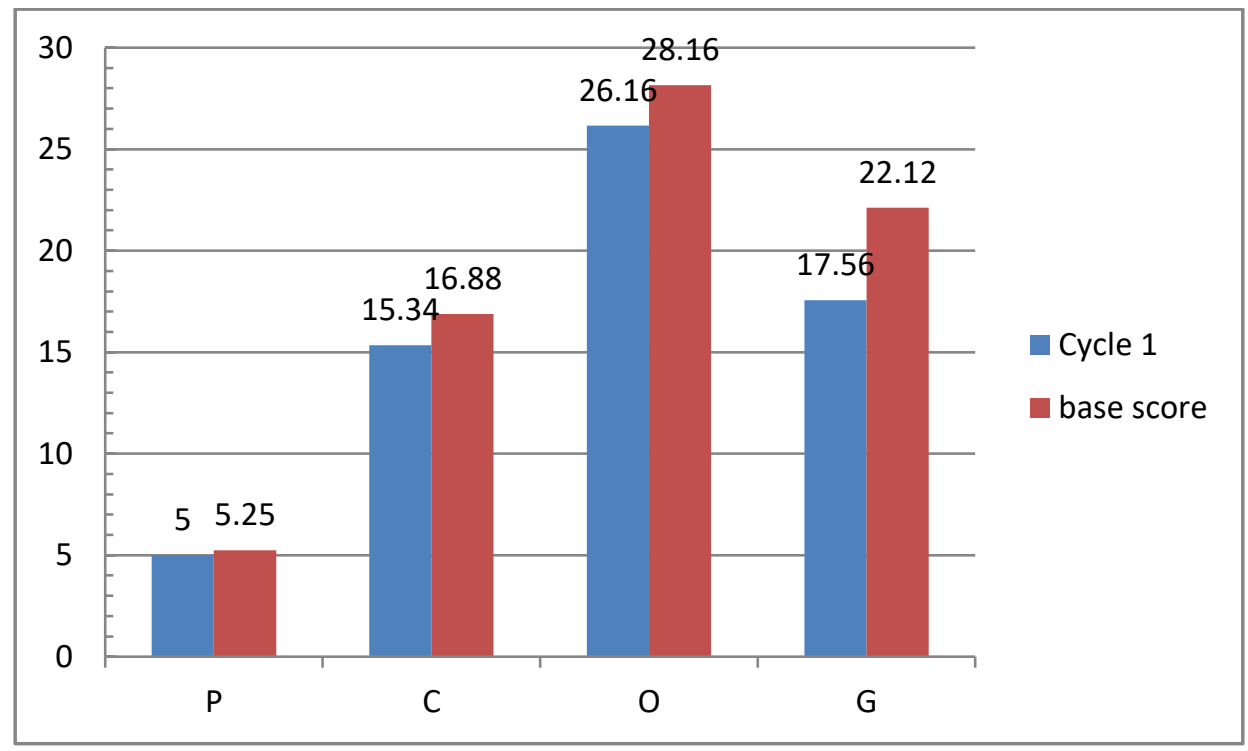


Diagram 4: The Improvement Writing Score in Cycle 1

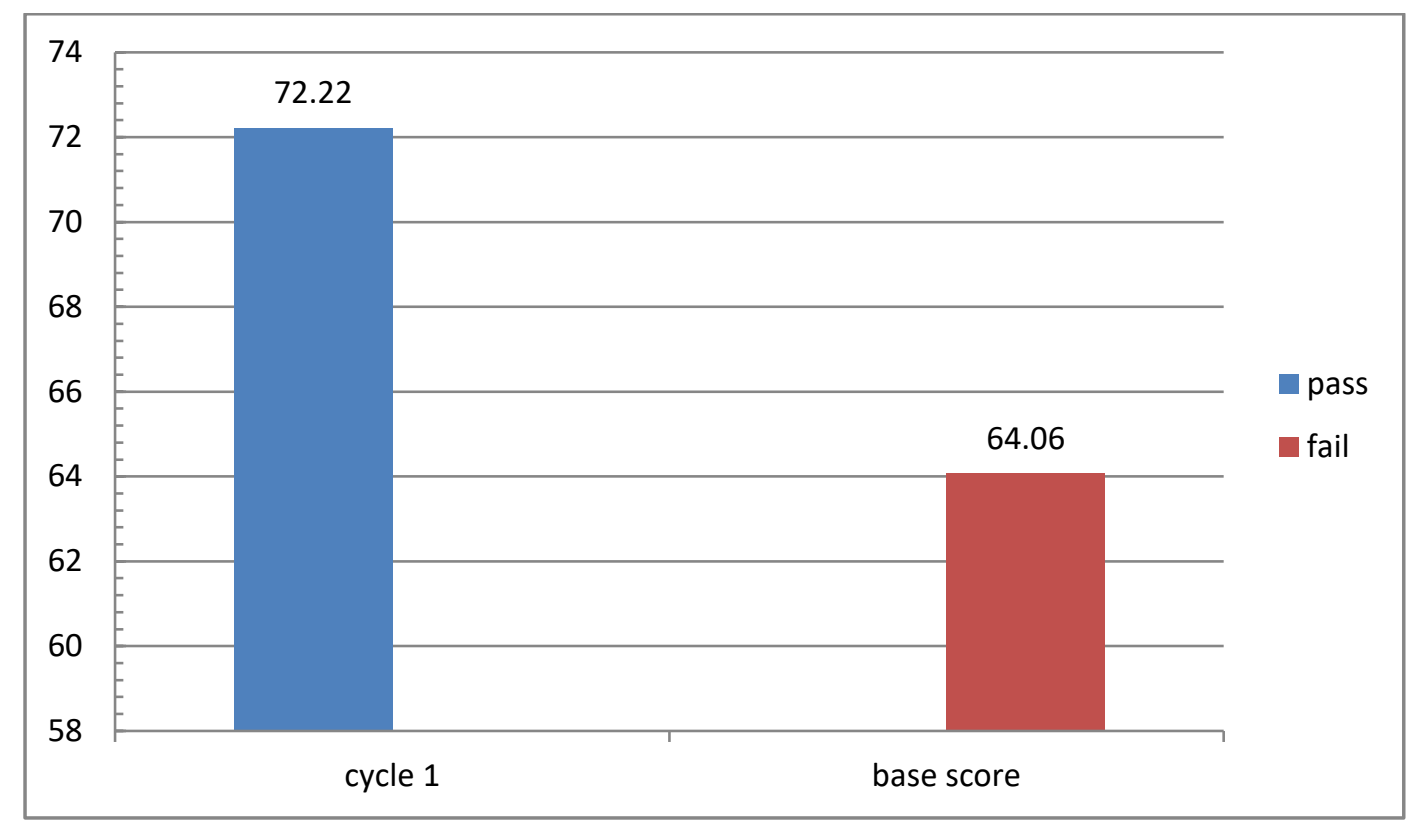

From the data explained, it showed the score was improved from the base score to cycle 1 . The cycle 1 score was below of standard of school criteria 75 .

\section{(iii) Observation}

The researcher observed the students how they did every task that the researcher had given in the class. The researcher asked the students to rearrange the scrambled pictures that the researcher had prepared. In detail, the observation could be seen in the description below:

\section{(a) First meeting}

The researcher introduced herself to the students of the Andalusia class of SMP Juara Pekanbaru. The researcher also explained the aim of her presents in their class that the researcher wanted to implement the research. The researcher explained scrambled picture media. In the first meeting, the researcher taught narrative text and also did a base score test to identify the students' writing skill. The researcher explained the generic structure of the text and also the language feature of the text. Then, the researcher asked the students did the practice rearranging the scrambled pictures. The text was about the example of narrative text, Cinderella. The students were confused to do the task. It could be seen when the researcher saw their answers. The students had many mistakes. The students were shy when the researcher asked them a question. The researcher tried to be close with the students, so the researcher hoped the students were not shy. The researcher helped to solve the problems that the students faced in the learning process.

(b) Second meeting

In the second meeting, the researcher asked the students to review previous material about scrambled picture media, narrative text, the generic structure and the language feature. After that, the researcher asked the students did the practice rearranging the scrambled sentences. The text was about the example of narrative text, Cinderella. The students looked began to understand the task. The students were not confident enough to write a text. The students were allowed to discuss the task with their group. The researcher helped to solve the problems that the students faced in the learning process.

\section{(c) Third meeting}

In the third meeting, the researcher asked the students to review previous material about scrambled picture media, narrative text, the generic structure and the language feature. After that, the researcher asked the students did the practice rearranging the scrambled pictures and sentences. The text was about the example of narrative text, Little match girl. The students were confident enough to write a text. The students were allowed to discuss the task with their group. The researcher helped to solve the problems that the students faced in the learning process.

\section{(d) Fourth meeting}

In the fourth meeting, the researcher asked the students to review previous material about scrambled picture media, narrative text, the generic structure and the language feature. After that, the researcher asked 
the students did the practice as before. The text was about the example of narrative text Pinocchio. The students were confident enough to write a text. The students were allowed to discuss the task with their group. The researcher helped to solve the problems that the students faced in the learning process.

(e) Fifth meeting

In the fifth meeting, the researcher asked the students to review previous material about scrambled picture media, narrative text, the generic structure and the language feature. After that, the researcher asked the students did the cycle 1 test. The researcher had prepared some topics. Then, the students chose one of the topics. All of the students were focused on finishing the test. After finish, the students collected to the researcher. The students did not look confused about the generic structure of narrative text anymore.

\section{d) Reflection}

From the analysis of cycle 1 , the researcher found that some students' improved writing skill in cycle 1 . Firstly, some students were confident to use and write English. Secondly, some students were could express their idea through writing. Lastly, the students follow the class rules during the learning process because learning using pictures as media interests them. Pictures did not make the students feel boring.
The collaborator and the researcher analyzed the result of cycle 1 . Based on cycle 1 the collaborator and the researcher feel the research would continue to cycle 2 . The average score of the students in cycle 1 reaches only 72,22, which still below of the school $K K M$. The students were failed, but the students' score was improved.

\section{Cycle 2}

\section{a) Planning}

From the reflection of cycle 1 the collaborator and the researcher feel the research must continue to cycle 2 . The average score of the students in cycle 1 reaches only 72,22 . The students were failed, but the students' score was improved.

Those finding demanded the researcher to give better treatment in the teaching-learning process by using scrambled picture by giving the students different stories from cycle 1 . The researcher tried to create activities for more stimulating the students.

After conducting the discussion with the collaborator, the researcher design five meetings in cycle 2, the researcher prepared everything needed, such as materials and lesson plans.

Table 7 The Schedule for Cycle 1

\begin{tabular}{cllll}
\hline Meeting & \multicolumn{3}{c}{ Material } & \multicolumn{1}{c}{ Date } \\
\hline 1 & $\begin{array}{l}\text { Implemented } \\
\text { Rapunzel }\end{array}$ & scrambled pictures & media: & Monday, 29 April 2019 \\
\hline 2 & $\begin{array}{l}\text { Implemented } \\
\text { Robinhood }\end{array}$ & scrambled pictures & media: & Tuesday, 30 April 2019 \\
\hline 3 & $\begin{array}{l}\text { Implemented scrambled pictures media: The } \\
\text { snail and the rabbit }\end{array}$ & Thursday, 2 May 2019 \\
\hline 4 & $\begin{array}{l}\text { Implemented scrambled pictures media: The } \\
\text { lion and the mouse }\end{array}$ & Saturday, 3 May 2019 \\
\hline 5 & Test cycle 1 & Monday, 5 May 2019 \\
\hline
\end{tabular}

\section{b) Action}

The researcher was taught the students by using the scrambled pictures media in the class. The teaching-learning process implemented in three stages: pre activities, main activities, and post activities. The pre-teaching activities include all done as opening the teaching-learning process, such as greeting and checking attendance. Then, the researcher told the students about a story than ask the students to guess what topic would be discussed. The main activities were the students' involvement in writing narrative text by applied the scrambled pictures media with their groups and individuals. After that, they collected their texts to the researcher as the teacher. The post activities were reviewing the lesson and all done as closing.
By implemented scrambled picture media, the researcher got the result of the test score. The students' mean score was 85,86 . According to the school's standard minimum, as explained above, the students were passed the test with significantly scores. It showed that the students passed by using scrambled picture media in the learning process. Comparing the cycle 1 score to the cycle 2 score showed that there was significant improvement between the cycle 1 score and the cycle 2 score. To get the cycle 2 score, the researcher conducted cycle 2 with a systematical process as plan, action, observation and reflection. After doing all those processes planned, the researcher gave the writing test to the students. The average score of cycle 2 was recapitulated as bellow: 
Table 8 Table of Students' Writing Score in Cycle 2

\begin{tabular}{cccccc}
\hline $\begin{array}{c}\text { Name of } \\
\text { Score }\end{array}$ & $\mathbf{P}$ & $\mathbf{C}$ & $\mathbf{O}$ & $\mathbf{G}$ & Score \\
\hline Rater 1 Score & 6,05 & 19,32 & 38,86 & 26,59 & 90,82 \\
\hline Rater 2 Score & 7,26 & 15,85 & 25,11 & 22,37 & 70,59 \\
\hline Rater 3 Score & 6,18 & 22 & 38,64 & 25,23 & 92,05 \\
\hline $\begin{array}{c}\text { Cycle 2 Score } \\
\text { (The mean) }\end{array}$ & $\mathbf{6 , 5 0}$ & $\mathbf{1 9 . 0 6}$ & $\mathbf{3 4 , 2 0}$ & $\mathbf{2 4 , 7 3}$ & $\mathbf{8 4 , 4 9}$ \\
\hline Category & & & & & Pass
\end{tabular}

Diagram 5: The Point of the Students' Writing Aspects in Cycle 1

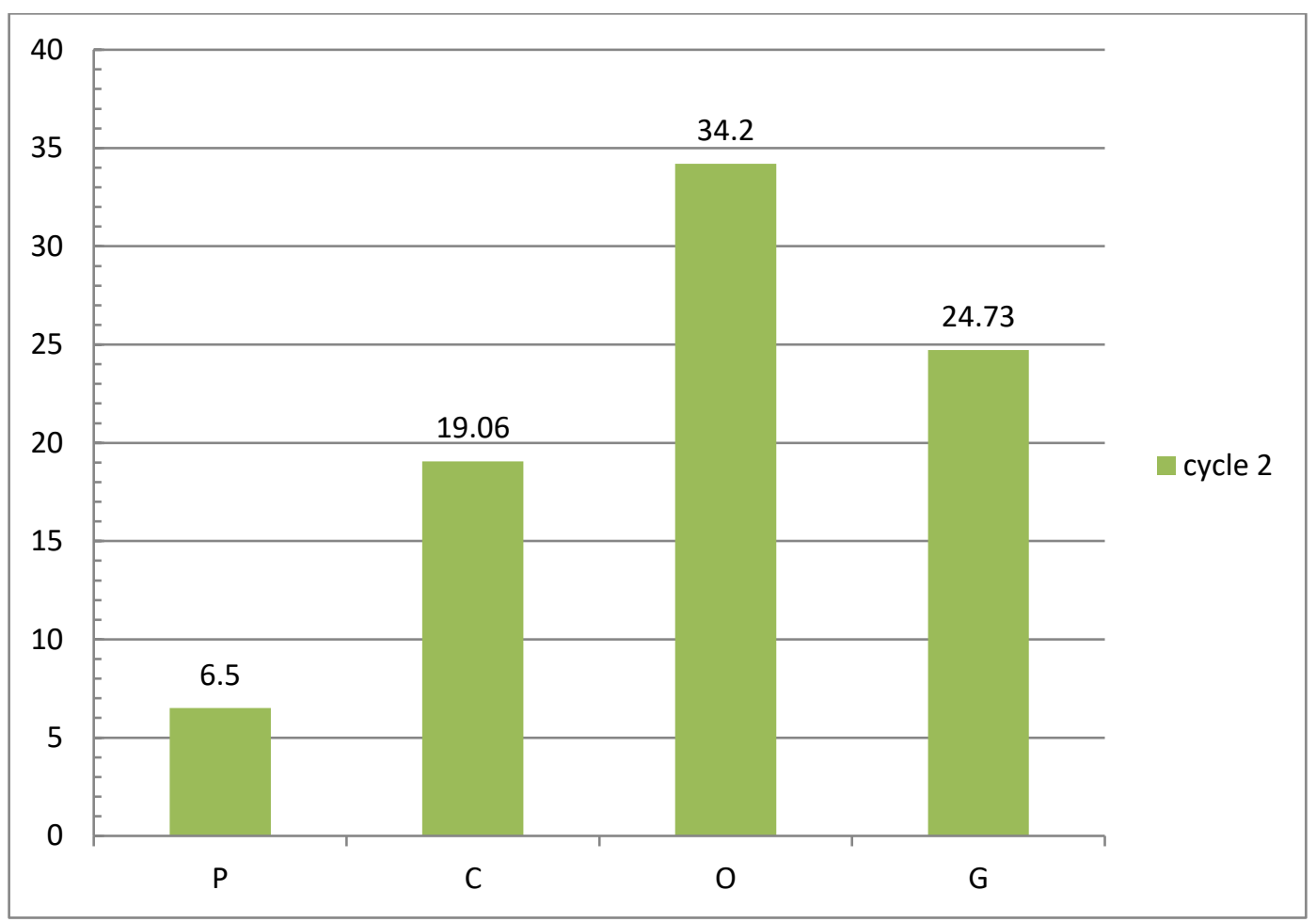

From the tables and diagrams above, it was identified that the students' writing score was significantly improved. To support the statement

above, the researcher appended the score recapitulations (see Appendix 6). The improvement point of writing aspects showed as the table below:

Table 9 Improvement Point of Writing Aspects in Cycle 2

\begin{tabular}{ccccccc}
\hline $\begin{array}{c}\text { Name of } \\
\text { Score }\end{array}$ & $\mathbf{P}$ & $\mathbf{C}$ & $\mathbf{O}$ & $\mathbf{G}$ & Score & Category \\
\hline $\begin{array}{c}\text { Cycle } 1 \\
\text { Score }\end{array}$ & 5,25 & 16,88 & 28,16 & 22,12 & 72.22 & Fail \\
\hline $\begin{array}{c}\text { Cycle } 2 \\
\text { Score }\end{array}$ & 6,50 & 19.06 & 34,20 & 24,73 & 84,49 & Pass \\
\hline $\begin{array}{c}\text { Improving } \\
\text { Impro3 }\end{array}$ & $\mathbf{1 , 2 7}$ & $\mathbf{4 , 4 7}$ & $\mathbf{3 , 2 4}$ & $\mathbf{1 0 , 6}$ & \\
\hline
\end{tabular}


Diagram 6: Improvement point of writing aspects in cycle 2

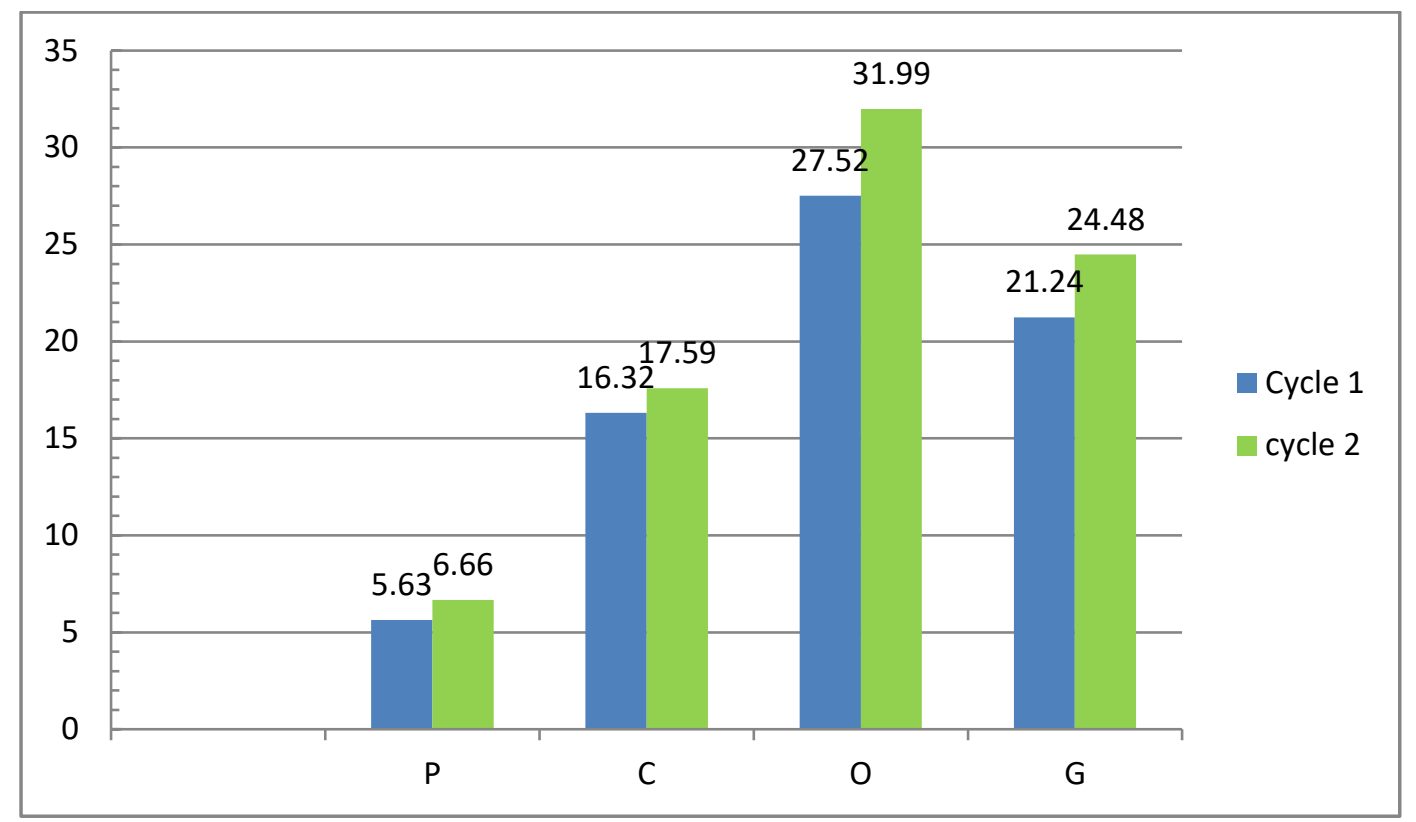

Diagram 7: The improvement writing score in cycle 1

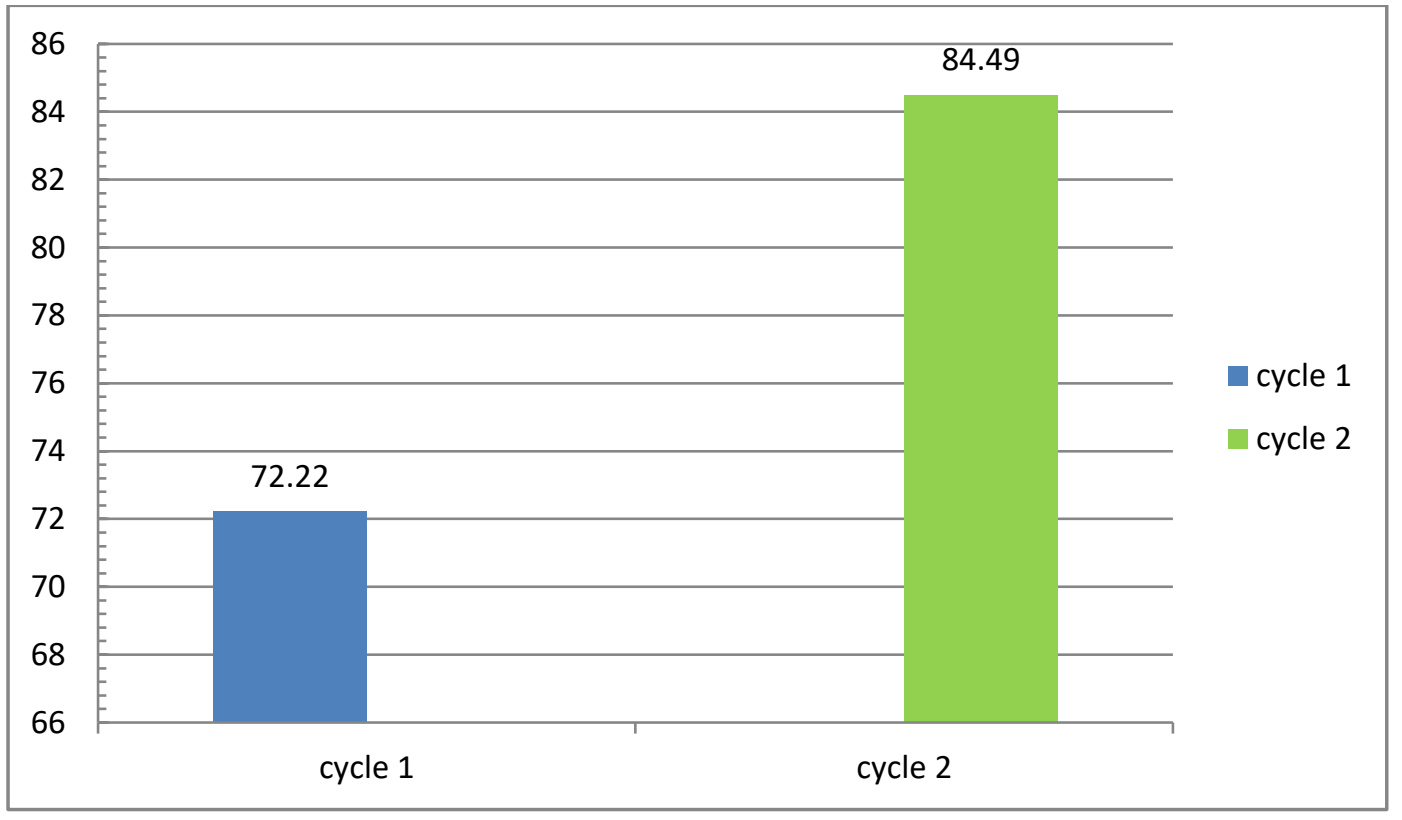

From the data explained, it showed the score was improving from cycle 1 score to cycle 2 score. The cycle 2 score was beyond the minimum standard of school criteria 75. Based on diagram 6 the biggest increase is in Organization with an increase of 4,47. In conclusion, scrambled picture media could improve the students writing skill, especially in Organization. The organization in the question are the paragraph begins with a clear orientation about the background of the story, the paragraph contains complication which the problem arises followed by other problem, the paragraph ends with an appropriate resolution (see table 1).

\section{c) Observation}

The researcher observed the students how they did every task that the researcher had given in the class. The researcher asked the students to rearrange the scrambled pictures that the researcher had prepared. In detail, the observation could be seen in the description below:

\section{(a) First meeting}

In the first meeting, the researcher explained scrambled pictures media. As before meetings, the researcher taught narrative text. After that, the researcher explained the generic structure of the text and also the language feature of the text. Then, the 
researcher asked the students did the practice rearranging the scrambled pictures and sentences. The text was about the example of narrative text, Rapunzel. The students were confident to write a text. The students were allowed to discuss the task with their group. The researcher helped to solve the problems that the students faced in the learning process.

\section{(b) Second meeting}

In the second meeting, the researcher asked the students to review previous material about scrambled picture media, narrative text, the generic structure and the language feature. After that, the researcher asked the students did the practice rearranging the scrambled pictures and sentences. The text was about the example of narrative text, Robinhood. The students looked began to understand the task. The students were confident to write a text. The students were allowed to discuss the task with their group. The researcher helped to solve the problems that the students faced in the learning process.

\section{(c) Third meeting}

In the third meeting, the researcher asked the students to review previous material about scrambled picture media, narrative text, the generic structure and the language feature. After that, the researcher asked the students did the practice rearranging the scrambled pictures and sentences. The text was about the example of narrative text, The snail and the rabbit. The students were confident to write a text. The students were allowed to discuss the task with their group. The researcher helped to solve the problems that the students faced in the learning process.

\section{(d) Fourth meeting}

In the fourth meeting, the researcher asked the students to review previous material about scrambled picture media, narrative text, the generic structure and the language feature. After that, the researcher asked the students did the practice as before. The text was about the example of narrative text, The lion and the mouse. The students were confident to write a text. The students were allowed to discuss the task with their group. The researcher helped to solve the problems that the students faced in the learning process.

(e) Fifth meeting

In the fifth meeting, the researcher asked the students to review previous material about scrambled picture media, narrative text, the generic structure and the language feature. After that, the researcher asked the students did the cycle 2 test. The researcher had prepared some topics. Then, the students chose one of the topics. All of the students were focused on finishing the test. After finish, the students collected to the researcher. The students did not look confused on the generic structure of narrative text anymore.

\section{d) Reflection}

From the analysis of the observation of cycle 2 , the researcher found that some students' improved writing skill in cycle 2. Firstly, most of the students were confident to use and write English. Secondly, most of the students were could express their idea through writing. Lastly, the students follow the rules in the class during the learning process because learning using pictures as media interested the students. Pictures did not make the students feel boring.

The collaborator and the researcher analyzed the result of cycle 2. Furthermore, the teaching-learning process was done well. The researcher and the collaborator felt satisfied because the students had improved from the score that they got from the base score and cycle 2. Therefore the researcher and the collaborator decided to stop the classroom action research because base score on the result of cycle 2 , it had already a success.

\subsection{The Factors that Influence the Students' in Writing Narrative Text}

The students' improvement from the base score to the cycle test score, the factors increased of the writing aspect could be identified from the observation checklist, field notes and interviewing the students at the end of the research. It could be clarified that the students did all the activities of scrambled pictures media. It could be seen from the field note form that has been filled by the collaborator. The collaborator filled the field note on everything that happened while the researcher conducted the media. There are some factors that influenced the improvement students' writing skill by using scrambled pictures media they were some factors. The factors were:

First, scrambled pictures media guides the students to involve in active and confident to write narrative text, based on the observation, it was recognized that the implementation of scrambled pictures media in each meeting mostly well (see the appendix 3, observation checklist), and then the students were confident to write a text because the students could use their idea to continue the topics that the researcher gave to them.

Second, scrambled pictures media makes the students enjoy and fun in learning narrative. Scrambled pictures media stimulate the students in improving writing skill while they were trying to complete the story, it could be seen on the result of interviewed the students, they said that they were happy to learn English writing narrative in the implementation of this media because it made them fun and enjoyable to learn the English writing (see the appendix 5), so they could express what they had in their mind easily without any anxiety of making mistake. They also paid attention to their friends and the class more active than before. 
Third, scrambled pictures media could motivate the students to learn the writing skill. It made the students to write and study the writing skill in the English class, based on the result of the students' interview (see appendix 5), almost all students had motivation to write active in the class, and tried to write as well as they know.

Therefore, after analyzing the data which were gathered from several sources such as writing score, observation, interview, and writing test, the researcher presents the answers to problems statements. This research carried out in two cycles, and the cycle consisted of ten meetings. It was conducted at the eighth-grade students of SMP Juara Pekanbaru, in order to overcome students' writing skill. The researcher applied scrambled pictures media to improve students' writing skill. The purposes of this research were to identify whether the scrambled pictures media could improve the students' writing skill. Based on the findings of this research, there was an improvement between the base score that the students before conducted the scrambled pictures media and the test score of students who were taught by using scrambled pictures media after conducted the media.

\section{Conclusions}

The researcher taught a narrative by using scrambled pictures media aimed to improve the students' writing skill. From the research's result it could be concluded that scrambled picture could improve the students' writing ability. It could be seen from the improvement of the base score and cycle tests of the students writing narrative text. The mean score of the students' base score was 65,60. After the researcher implemented scrambled pictures media, the mean score of the cycle 1 was 75,26, and cycle 2 was 85,86 . It showed that there were improvements of the students' writing ability. Based on the explanation above, it could be concluded learning by using scramble picture required creativity and cooperation of the students in the group. It was also an interesting media that can improve the students' motivation in making writing text, especially in narrative text.

\section{References}

Aen, Khurotul. 2010. The Effectiveness of Using Scrambled Pictures to Improve the Student' Ability in Speaking Narrative Text. Unpublished Thesis. Walisongo State Institute for Islamic studies.

Airasian, P and L. R. Gay. 2000. Educational Research: Competencies for Analysis and Application Sixth Edition. New Jersey: Prentice Hall Inc.

Anderson, Mark. 1997. Text Type in English 2. Australia: Mackmillan.
Arikunto, S. 2010. Prosedur Penelitian Suatu Pendekatan Praktik. Jakarta: Rineka Cipta.

Ary D., Jacobs L. C., Sorenson \& Razavieh. (2010). Introduction to Research in Education. USA: Wadsworth cengage learning.

Arsyad, Azhar. 2003. Media Pembelejaran. Jakarta: PT Raja Grafindo Persada.

Brown, H. Douglas. 2000. Teaching by Principles: An Interactive Approach to Language Pedagogy. New York: San Francisco state university: Wesley. Longman,Inc.

Ferrance, E. (2000). Themes in education action research. Northeast and Islands Regional Educational Laboratory at Brown University.

Harmer, Jeremy. 2004. How to Teach Writing. New York: Longman

Harmer, Jeremy. 2007. The Practice of English Teaching. New York: Longman

Kemmis, S. \& McTaggart, R. 2007. Participatory Action Research.

Khasanah, N. U. (2015, July). The Influence of Using Scrambled Pictures to Improve Students' Ability in Writing Narrative Text of Eleventh Grade Students of SMK Bhakti Utama Bandar Lampung. In International Multidiciplinary Conference on Social Sciences (IMCoSS) (Vol. 1, p. 91).

Mariam, Siti. 2016. The Effectiveness of Using Scrambled Pictures to Teach Speaking of Narrative Text. Thesis. Walisongo State Islamic University.

Nation, I.S.P. (2009). Teaching ESL/EFL Reading and Writing. New York and London: Routledge Publisher.

Nunan, D. 1989. Designing tasks for the communicative classroom. D. Nunan (Ed.). Cambridge : Cambridge University Press.

Oshima, A. and Hogue, A. (2007). Introduction to Academic Writing. Third Edition. New York: Pearson Eduscation, Inc.

Sudijono. Anas. 2009._Pengantar Statistik Pendidikan. Jakarta: PT. Raja Grafindo.

anum, R. S., Sutarsyah, C., \& Hasan, H. (2014). The Effectiveness of Using Scrambled Pictures In Increasing Students' Reading Ability. U-JET, $3(2)$.

Yunita, Ria. 2017. Improving Students' Writing Ability in Narrative Text by Using Scrambled Pictures at Eight grade students of SMP PGRI 2 Karangmalang Sragen in Academic Year 2015/2016. Thesis. The State Islamic Istitute of Surakarta 